\title{
The Organizational Evolutions and Strategies of Family Businesses in Taiwan
}

\author{
Chu-Ching Wang1, Hsiu-Chen Chuang2, Nien-Tsu Liu',3, Hsu-Shih Shih ${ }^{2}$ \\ ${ }^{1}$ Department of Business Administration, Tamkang University, Taipei, Taiwan \\ ${ }^{2}$ Department of Management Sciences, Tamkang University, Taipei, Taiwan \\ ${ }^{3}$ Department of Food and Beverage Management, Mackay Junior College of Medicine, Nursing, and \\ Management, Taipei, Taiwan \\ Email: chuching@mail.tku.edu.tw, sherley@mail.tku.edu.tw, flence888@yahoo.com.tw, \\ hshih@mail.tku.edu.tw
}

Received 23 August 2014; revised 22 September 2014; accepted 15 October 2014

Academic Editor: Grigorios L. Kyriakopoulos, National Technical University of Athens (NTUA), Greece

Copyright (C) 2014 by authors and Scientific Research Publishing Inc.

This work is licensed under the Creative Commons Attribution International License (CC BY).

http://creativecommons.org/licenses/by/4.0/

(c) (i) Open Access

\section{Abstract}

The family is, no doubt, the oldest and longest running social unit in our world. Families were formed along with small communities long before commerce began. In fact, families, often in connection with the local communities, sustained themselves by self-sufficient means [1]. Family businesses are most popular and play an important role in lots of countries, and also are the cornerstones of economic development in Taiwan. They not only expanded the Taiwan economy, participated and witnessed the economic miracle in the past, but also formed the main part of overall enterprise structure in Taiwan through creating a great deal of employments, and thus made a stable and prosperous social life [2]. Many large enterprises in Taiwan are composed by family business, and most of them were growing up and becoming robust after going through obstacles in the way. For example, the leading manufacturing company, Foxconn Technology Group was mold and die manufacturer at first, and many companies from the 10 biggest international brands published by the Ministry of Economic Affairs (2012) [3] such like ASUS, ACER, MAXXIS and GIANT were also grown up from family business or small enterprises. Now they are the models and mirrors for the family business. Through observation and review of mass literatures, this paper explores the organizational evolutions in structure and the possible appropriate strategies for the family businesses in Taiwan. The major findings in this study are: 1) the organizational evolutions are from simple structure to functional, divisional and compound structure; 2) the leadership patterns are from affection-directed to regulation-directed and rationality-directed approach;3) the strategies are from localization to internationalization. Finally, this paper constructs an integrated model based on above findings. 


\section{Keywords}

\section{Family Businesses, Organizational Evolution, Strategy, Leadership Pattern, Integrated Model}

\section{Introduction}

Family businesses (called family-type enterprises) in our society and economy have strong historical presence and widespread presence, as well as vital economic and social contributions [4]. The prevalence of family firms as the most prevalent business structure in the USA has been documented worldwide [5] [6]. Throughout history, families have been critical to the creation and operation of businesses. Families are the most important sources of human capital, social capital, financial capital, and physical capital. Worldwide, from ancient to modern times, and from agricultural and cottage industries to multinational corporations, family ownership is pervasive [7], Morck and Yeung (2004) [8]. For example, note that in some countries, like Mexico, family firms make up about 100 percent of all firms, in others, like Sweden, they represents about 50 percent of all firms, and in other yet, as the USA and the UK, family firms are a minority.

A family business group is the typical family enterprise in Asian region and most economics outside of the United States [7]. It has also played an important role in Taiwan's economy; over eighty percent of the companies in Taiwan are family-type enterprise. Even most of listed companies are still controlled by some families. According to 2012CCIS [9] "large conglomerates in Taiwan Study" found that the global sales of the top 100 Taiwanese business groups was US\$1.99 trillion (NT\$59.63 trillion), Hon Hai Group (Foxconn) was ranking No. 1 for five consecutive years, and continues to rewrite its record for group revenue about US\$12.24 billion (NT\$3 trillion 6726.48 billion); The second is the Formosa Plastics Group about US\$ 7.2 billion (NT\$2 trillion 156.134 billion); and No. 3 was Quanta Group about US\$3.6 billion (NT\$1 trillion 109.728 billion). The most of listed 100 companies are still controlled by some families. Another survey from Taiwan Institute of Directors (TWIOD) [10] in 2012 reported that China, Hong Kong and Taiwan had total 4992 listed companies; about 45\% was family businesses, and Taiwan had the most. More than 70 percent is still family business in Taiwan; Taiwan is not only a "technology island" but also a "family business island."

According to the White Paper statistical data collected by Small and Medium Enterprise Administration, Ministry of Economic Affairs (SMEA) in 2011 [11], the total number of family business in Taiwan has been more than 1.1 million, which accounts for $97.72 \%$ of the overall enterprises, with 7.36 million employment which accounts for $77.89 \%$ of total employment. Whereas in OECD member countries, the SMEs accounts for $95 \%$, bringing forth $50 \%$ of total value-added and creating $60 \%$ to $90 \%$ of new jobs, which shows the family business also play a crucial role in industrialized countries, or even serve as the key suppliers of components for large enterprises in the industrial supply chain.

The contribution of family-type enterprises to the economic development in Taiwan is very significant. Undoubtedly, the history of family-type enterprises can be regarded as the evolution of economic development in Taiwan [12]. Thus facing the dynamic and keenly competitive environments, we envision the possible trends for the government and private enterprises to formulate the appropriate strategies. Facing the dynamic and keenly competitive environments, therefore, this paper will explore the organizational evolutions in structure and the following appropriate strategies for the family businesses.

Family businesses differ from other firms in terms of ownership, management and social philosophies, approach to leadership and relationships [13] [14]. The involvement of the family is the key defining issue that differentiates family business from non-family business. There are many definitions of a family business. The definitions take into account many aspects, such as family ownership, involvement of the management, strategic control, the main source of income for the family and intergenerational transfers. The European Commission Report also notes that self-employed/one-person enterprises are considered as family businesses in approximately one-third of the countries surveyed.

From an academic perspective, family business has been defined in many ways. Chua et al. [15] defined family business as "a business governed and/or managed with the intention to shape and pursue the vision of the business held by a dominant coalition controlled by members of the same family or a small number of families in a manner that is potentially sustainable across generations of the family or families". From a practitioner perspective, Astrachan et al. [16] suggest that family business vary in their "familyness" and that it is the degree to which the family determines the behavior and direction of the business matters. Others have defined it as "one 
that will be passed on for the family's next generation to manage and control” [17]. The literature indicates that family businesses differ from non-family businesses due to the unique involvement of the family members [15]. Chua et al. [18] suggest considering the key topics as ownership, governance, management and succession in family business investigation. However, Basco and Pe'rez Rodr1'guez [19] state that many authors have now categorized family business into four key areas: strategic process, governance, human resources and succession, thus the only commonality is succession and governance. This is fundamentally important as it suggests succession and governance is solid foundation of the family business theory. It is therefore somewhat mysterious as to why it is that few academic research studies have focused on the family as the unit of study. Research projects that have taken the family system as a unit of study are unusual but important if we try to extend theory in this field [20].

In reality, there are two types of powers operating in any enterprise-i.e., management and ownership. Management seems to play a more important role in the performance of business operations. A family business group is an inter-linked network in management and ownership among affiliate firms that each affiliate firm will be corrected with its engaged environments in different manners [21]. Like other kinds of family enterprises, a family business group is characterized with the impact from family management and ownership on strategic decisions [22]. In the United States, although not many families own absolutely most shares in some enterprises, those families can still influence and control the company's decisions and operations through some methods such as holding many preferred stocks [23] [24]. For the big enterprises in Taiwan, particularly those listed ones; they often own relatively more ownerships and thus can influence the operations of company such as the Formosan Plastics and Tatung groups. In fact, the greater ownership one family has held, the more influence on the company's management it can have. Nevertheless, the major determinant of a business's performance is the "management", not the "ownership."

In order to delineate the changing trends for the management of the family businesses in Taiwan, this paper adopts the perspective of organization theory to propose an "environment $\rightarrow$ strategy $\rightarrow$ structure" model [25].

\section{Organizational Evolutions of Family Businesses}

The growth of a company is often from simple to complex, and the family business is not exceptional. The strict linkage between family and company is one of the primary characteristics [26]. The family unit brings together and creates the forces enabling the emerging and sustained entrepreneurial behavior. The conceptualization of the family business must encompass a multidisciplinary and comprehensive perspective of the complex and dynamic phenomenon of business that is owned and operated by family members [27]. In addition, due to the strong family ethics - the young and old order, at the establishment stage most members at management levels of the company is almost same as the order of families. This kind of top-down consistency between the primary group (i.e., the family) and the secondary group (i.e. the company) is advantage for the directing relationship between top-down levels in the company. This simple structure usually is found at the start of the company. Figure 1 shows the possible symmetry between the family and the company structure.

Throughout history and across countries, families and business have always existed to a large extent in conjunction with each other [27]. The economic necessity of earning a living and supporting a family is often the underlying motivation for starting and growing a business [27]. When the family businesses grow gradually, it is necessary to arrange different departments in order to achieve the effectiveness of specialization. Departmenta-

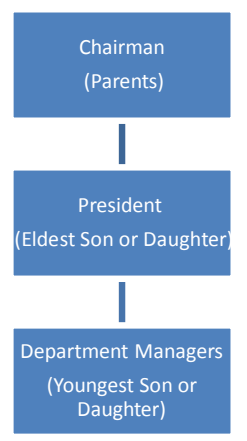

Figure 1. The simple structure. 
lization will result in differentiated horizontal groups, and no any one group shows more important. Theoretically, therefore, the power among those departments is equal [28]. But the family ethics exert impact more or less on the company's operations.

There is no direct authority of command existing among the members in this kind of structure, and they often interrupt and command mutually with no intention. This will break intangibly the family ethics, particularly the head of each department may direct the employee who belongs to other department. This kind of authority just means the functional authority which exists in the functional structure (see Figure 2). This structure usually violates the principle of unity of command and results in the conflict, which happens frequently among superiors. Scholars also note their potential for conflict and discord is far greater than all other forms of ownership and management [29]. Family businesses are particularly likely to conflict due to the "dominant presence of the family, setting the rules and having ultimate power, the lack of formalized systems and structures to deal with conflict, and having no formal organizational structure or operative system and the co-mingling of business and family roles”' [20] [30]. Conflicting appraisals or situations appraised as both congruent and incongruent with desires and goals elicit both positive and negative emotions resulting in conflicting mixed emotions or emotionalcontradiction. For example, a family founder might experience both a negative (e.g., sadness from the loss of personal recognition) and a positive (e.g., pride in an offspring) emotion after leadership of the firm is transitioned to the next generation. This type of emotional ambivalence is particularly relevant to the family business environment as there is a high likelihood for conflict happen when determines the business decisions. Furthermore, although dysfunctional and conflicting relationships exist in both family and non-family firms, in family businesses, the conflict among family members in family businesses is more likely to be preserved with the hope that it will eventually be resolved [31]. Of course, some conflicts are beneficial; however, dysfunctional conflicts any influence the company's performance due to the tunnel vision.

While the family-type enterprises expand, diversification often is the strategy to grow and the divisional structure may follow. There are two types of divisional structure: M-form (for Multi-divisional) and H-form (for Holding), the former is based on multiple businesses in related areas within the company, and the latter is a holding company that results from unrelated diversification. Under this structure, the head of each department (usually the family member) is easier to devote and commit himself (herself) to his (her) department and the positive result will be achieved due to the strong will of winning. This kind of structure is showed in Figure 3.

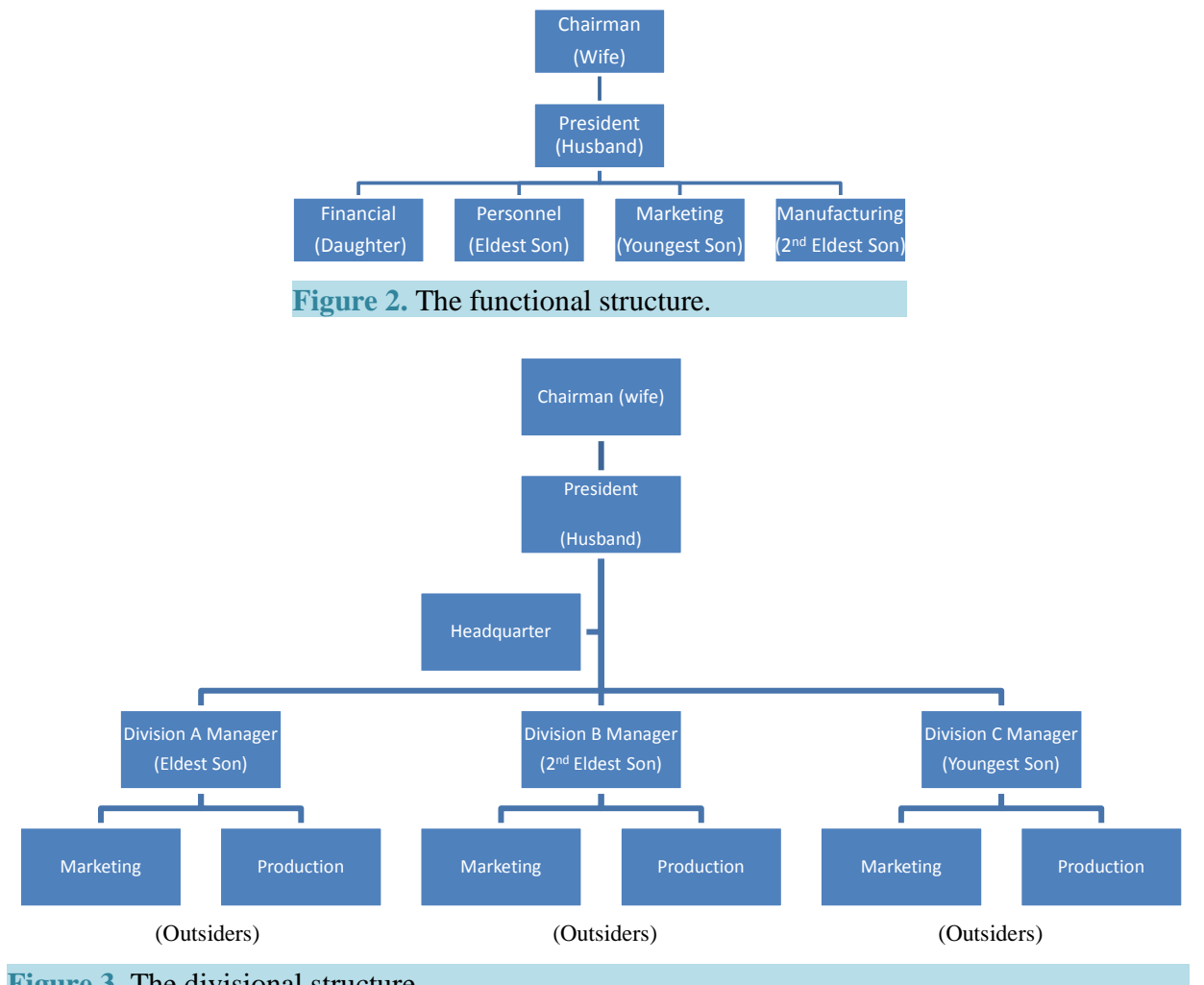

Figure 3. The divisional structure. 
Additionally, rational and professional management will result due to no pressure from the family. Of course, some potential problems may happen for this kind of federal division of labor; that is, if the core power of the top level changes dramatically (e.g., the death of chairman), the company may break down and the sons or daughters may separate to establish their own businesses. On the other hand, however, it is hard to say that whether the separation is good or bad if we view from the rule "long togetherness brings separation, long separation brings togetherness."

Because the dynamic environments bring vigorous competition, the possible last growth stage for the family businesses is to combine with other outside company through some strategies such as joint venture. Maybe no any one family can control the company in this kind of compound structure. The order of above three structures is the growing process of family-type enterprise. Table 1 compares briefly the related organizational features.

\subsection{Management/Leadership Patterns: From Affection-Directed to Regulation-Directed and Rationality-Directed Approach}

After reviewing the organizational features of Table 1, we can find that there are three different leadership patterns used: they are affection-directed, regulation-directed, and rationality-directed separately [20] [32].

\subsection{Environment and Strategy: From Localization to Internationalization}

Each of the three structures mentioned above has its value; that is, it is the effective organization as long as it fits with the environment. Facing the current trends of internationalization and deregulation, due to some domestic push (such as higher labor cost, market saturation, and higher consciousness of environment-protection in home country) and foreign pull (such as governmental policy of encouraging investment, lower labor cost, and near to market in host country), many family businesses are forced to go abroad to continue their business through increasing investment or cooperation with other companies. Like other kinds of family enterprises, a family business group is characterized with the family involvement on strategic decisions. However, whether family management and ownership will generate impact on the internationalization decision is more complex in a family business group since this kind of family business is composed with multiple affiliate firms achieve for the mutual goals [33]. The concentrated and pyramidal ownership and the desire to control in family business groups may cause them deciding to have less investment in global markets [21] [22] or choosing to invest in the nearby locations [34]. Others indicate that the distinctive family management and family capital would be helpful for family business groups in cross border expansion [35]. We are hardly to explain whether family involvement will generate incentive or entrenchment influence on the internationalization decision from one single lens since a family business group is a complex network that may be correlated with the environments in multiple dimensions [36]-[38].

This kind of development from internal to external is not usually desirable for the family-type enterprise to pursue due to higher risk. But it seems to be necessary to choose this strategy and take the risk because that it can continue to bequeath internally generation by generation and keep externally the honor of the family. This phenomenon is also the opportunity to change the constitution of domestic family businesses. Eventually, the company may be enlarged to conglomerate business if the stake is successful; but the failure may result the company to go bankrupt. Although the risk is very high, lots of family businesses enterprises till take it without hesitation because it is a matter of life or death if they don't internationalize or diversify.

Table 1. Comparison among the three structures of family businesses.

\begin{tabular}{cccc}
\hline Structure Characteristics & Simple Structure & Functional Structure & Divisional Structure \\
\hline Match between Family and Company (Strictness) & High & Medium & Low \\
Type of Authority & Line & Function & Line \& Staff \\
Chain of Command & Clear & Not Clear & Clear \\
Responsibility & Not Clear & Medium & Clear \\
Coordination Needed among Departments & Medium & High & Low \\
Leadership Pattern & Affection-directed & Regulation-directed & Rationality-directed \\
\hline
\end{tabular}




\subsection{The Integrated Model}

According to the evolutional trends mentioned above, an integrated model is developed as Figure 4. The model shows the management direction of family-type enterprises in Taiwan developing from the simple structure (i.e., single business, which focuses on domestic market, managed by affection-directed leadership) to divisional structure (i.e., multi-business, which focuses on foreign market, managed by rationality-directed leadership). Of course, an excellent family business is not always based on above approach. In other words, a small domestic and affection-directed company can also achieve its goal and bequeath generation by generation as long as the strategy is appropriate and management is effective. This is just the philosophy of "small is beautiful" [22].

Family-controlled business groups are less likely than non-family-controlled business groups to divest themselves of unrelated businesses [39]. Family-dominated business groups' limited experience in organizational adjustments will translate into a lack of specific managerial experience required to reduce dynamic adjustment costs [40]. As discussed earlier, the development of dynamic managerial capabilities requires the group-level managers to have experience in organizational adjustment. Eventually, business groups' expansion into international markets can become unmanageable owing to high levels of dynamic adjustment costs. In other words, dynamic adjustment costs reduce family-dominated business groups’ propensity to engage in international investment.

\section{Suggestions}

Although family business as a field of academic study is recent and still emerging, scholars have begun to recognize the importance of family businesses and their connection to entrepreneurship [41]. The prevalence of family firms as the most prevalent business structure in the USA has been documented [42] worldwide. The entrepreneur is a central and vital player in the entrepreneurial phenomenon, but he or she is only part of the total picture [27]. A new broader and more comprehensive view or approach, based on the concept of family entrepreneurship and the family business, may be the most accurate description of most businesses throughout the world [42]-[45].

The evolutional trends are found in this paper. It presents the following managerial implications and suggestions for Taiwanese family businesses:

1. While the family businesses grow continuously, the strategy should be modified; that is, from single business to multi-business and from individual ownership company to compound enterprise.

2. Due to the complex and dynamic environment, the professional outsiders should be recruited and promoted to important or higher position.

3. Regulation-and rationality-directed leadership should replace the affection-directed approach to manage the diversified organization.

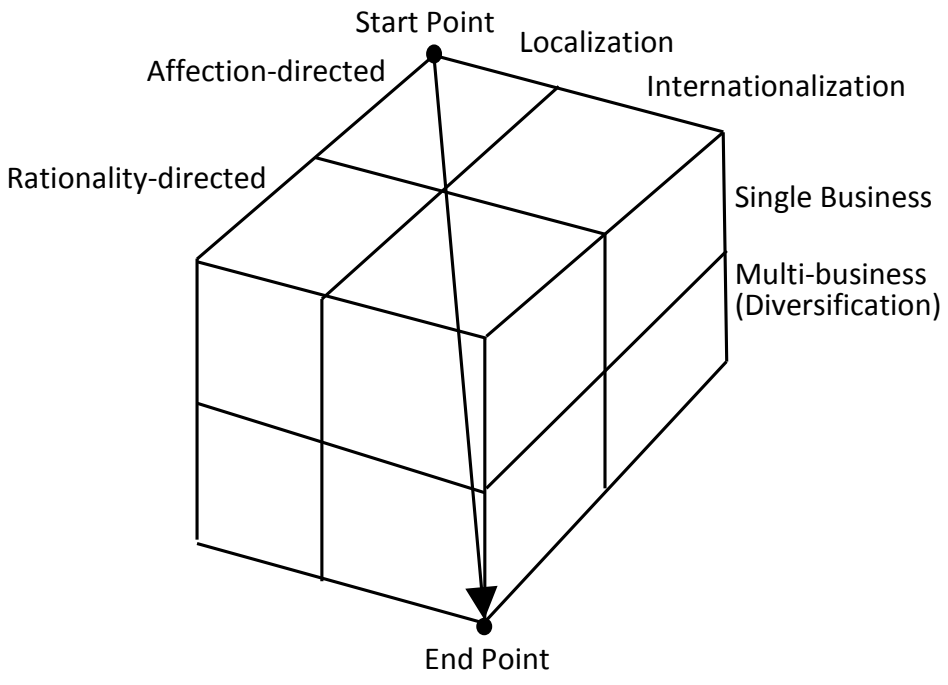

Figure 4. The integrated model of family-type enterprise evolution. 
4. A family business group is a distinctive family enterprise that develops closely with its embedded environment. Thus, the single institutional environment in this research will generate limitations in addressing family impact issues in family business groups under different institutional environments. Comparative research on family business groups in Asia is another possible direction to advance understanding of coordination and control issues in family enterprises [36].

5. The critical contributing factors of entrepreneurship including the personal faith of entrepreneur, personal relationship, the spirit of pursuing further education and centralized organizational structure are important during the starting-up phase. The self-skill and knowledge of the entrepreneur would not influence the entrepreneurial strategies adopted afterwards; however the spirit of pursuing further education will be high recognition to entrepreneur [46].

6. There is a need to enhance and expand the related education and training about the management of family businesses. There exists a notable paucity of entrepreneurship education and family businesses management training on family-business-specific topics [47]-[50]. Few of the students have access to modules or programmes which address the practical and theoretical aspects to family businesses, such as governance, succession and family dynamics [47]. Family businesses often face typical management and growth problems that require specific training areas, for instance, succession planning, conflict management, accounting and finance skills, or cross cultural studies issues [48]-[51]. Furthermore, in order to answer the local demands of economies and cultures, they have to base on the characteristics of the local area and economics to have the interaction of local networks to produce unique family business programs [52]. Governmental policy needs to be developed, which will support the next generation in a positive way by teaching about the family businesses [47].

7. It is especially critical for resource constrained family businesses to realize that many competitive strategies needed for success in today's market place cannot be implemented without information technology (IT) support [52]-[55]. From the perspective of innovations diffusion and technology acceptance model (TAM), family businesses managers' prior knowledge and IT ability, businesses location, and community size/type are key factors to technology adoption and implementation. Moreover, ease of use and decision to adopt IT accounted for over $60 \%$ of the variance in usefulness of IT and implementation of internet and IT capabilities. The implementation of IT capabilities accounted for nearly $40 \%$ of the variance in actual use of IT and perceived impact of the internet [54]. Although researchers don't suggest the complexities of managing and sustaining family businesses through IT, IT can provide specific capabilities to manage needs, and potential sources of conflict in family businesses [54] [56]. Besides, IT also is a driver of corporate governance [54] [55] and provides the foundation for effective internal controls [55] [57]. Of course, the incorporation of IT can be a means of internal control in an attempt to achieve good corporate governance which can enhance their efficiency and effectiveness [55].

8. Family businesses have been criticized by governmental policy makers for their poor governance structures [58]. In many ways, the governance of family businesses is more rough and complex than the firm with no family involvement [59]. Common recommendation to family businesses is to increase the number of independent, outsider directors on their boards [58]. What often takes place in the family businesses, even though different degrees of intensity, is an overlapping of ownership and governance, rather than their separation [60]. For enhancing the performance of a family business, therefore, it is necessary to separate both ownership and governance. Finally, the government must strengthen laws that protect shareholder interests and increase enforcement of such laws and regulations to improve corporate governance. Besides, firms must also act to improve this situation [61].

\section{References}

[1] Ponzetti, J.J. (2003) International Encyclopedia of Marriage and Family. 2nd Edition, Macmillian Reference, New York.

[2] Tsai, W.C. (2014) An Exploratory Study of Entrepreneurship in Taiwan’s Small \& Medium Enterprises—Case Studies of Six Manufacturing Companies. Information Management and Business Review, 6, 109-114.

[3] (2012) White Paper on Small and Medium Enterprises in Taiwan.

[4] Heck, R.K.Z. and Stafford, K. (2001) The Vital Institution of Family Business: Economic Benefits Hidden in Plain Sight. In: McCann, G.K. and Upton, N., Eds., Destroying Myths and Creating Value in Family Business, Deland, Stetson University, 9-17. 
[5] Bosma, N., Jones, K., Autio, E. and Levie, J. (2008) Global Entrepreneurship Monitor: 2007 Executive Report. Babson College, Babson Park, MA and London Business School, London.

[6] International Family Enterprise Research Academy (IFERA) (2003) Family Businesses Dominate. Family Business Review, 16, 235-240.

[7] Zachary, R.K. (2011) The Importance of the Family System in Family Business. Journal of Family Business Management, 1, 26-36. http://dx.doi.org/10.1108/20436231111122263

[8] Morck, R. and Yeung, B. (2004) Family Control and the Rent-Seeking Society. Entrepreneurship Theory and Practice, 28, 391-409. http://dx.doi.org/10.1111/j.1540-6520.2004.00053.x

[9] CCIS (2013) 2012 Business Groups in Taiwan. China Credit Information Service Ltd., Taiwan.

[10] TWIOD (2013) 2012 Business Performance from China, Hong Kong and Taiwan. Taiwan Institute of Directors, Taiwan.

[11] (2011) White Paper on Small and Medium Enterprises in Taiwan.

[12] Chen, M.C. (1984) How the Family-Type Enterprises to Modernize Their Management? Common Wealth, Taipei.

[13] Collins, L. and O’Regan, N. (2011) Editorial: The Evolving Field of Family Business. Journal of Family Business Management, 1, 5-13. http://dx.doi.org/10.1108/20436231111122245

[14] Miller, D. and Le Breton-Miller, I. (2005) Management Insights from Great and Struggling Family Businesses.Long Range Planning, 38, 517-530. http://dx.doi.org/10.1016/j.lrp.2005.09.001

[15] Chua, J.H., Chrisman, J.J. and Sharma, P. (1999) Defining the Family Business by Behaviour. Entrepreneurship Theory and Practice, 23, 19-37.

[16] Astrachan, J.H., Klein, S.B. and Smyrnios, K.X. (2002) The F-PEC Scale of Family Influence: A Proposal for Solving the Family Business Definition Problem. Family Business Review, 15, 45-58. http://dx.doi.org/10.1111/j.1741-6248.2002.00045.x

[17] Ward, J.L. (1987) Keeping the Family Business Healthy: How to Plan for Continuous Growth, Profitability, and Family Leadership. Jossey-Bass, CA.

[18] Chua, J.H., Chrisman, J.J. and Sharma, P. (2003) Succession and Non-Succession Concerns of Family Firms and Agency Relationship with Nonfamily Managers. Family Business Review, 16, 89-107. http://dx.doi.org/10.1111/j.1741-6248.2003.00089.x

[19] Basco, R. and Pérez Rodríguez, M.J. (2009) Studying the Family Enterprise Holistically: Evidence for Integrated Family Business Systems. Family Business Review, 22, 82-95. http://dx.doi.org/10.1177/0894486508327824

[20] Bee, C. and Neubaum, D.O. (2014) The Role of Cognitive Appraisal and Emotions of Family Members in the Family Business System. Journal of Family Business Strategy, 5, 323-333. http://dx.doi.org/10.1016/j.jfbs.2013.12.001

[21] Granovetter, M. (1995) Coase Revisited: Business Groups in a Modern Economy.Industrial and Corporate Change, 4, 93-130. http://dx.doi.org/10.1093/icc/4.1.93

[22] Yiu, D.W., Lu, Y., Bruton, G.D. and Hoskisson, R.E. (2007) Business Groups: An Integrated Model to Focus Future Research. Journal of Management Studies, 44, 1551-1579. http://dx.doi.org/10.1111/j.1467-6486.2007.00735.X

[23] Anderson, R.C. and Reeb, D.M. (2003) Founding-Family Ownership and Firm Performance: Evidence from the S\&P 500. Journal of Finance, 58, 1301-1327. http://dx.doi.org/10.1111/1540-6261.00567

[24] Arregle, J.L., Hitt, M.A., Sirmon, D.G. and Very, P. (2007) The Development of Organizational Social Capital: Attributes of Family Firms. Journal of Management Studies, 44, 73-95. http://dx.doi.org/10.1111/j.1467-6486.2007.00665.x

[25] Chou, L.F. (1995) Family-Type Enterprise (Translated from D.T. Taffe). Business Weekly, Taipei.

[26] Mintzberg, H. (1983) Structure in Fives: Designing Effective Organizations. Prentice-Hall, Inc., Englewood Cliffs.

[27] Zachary, R.K. and Mishra, C.S. (2011) The Future of Entrepreneurship Research: Calling All Researchers. Entrepreneurship Research Journal, 1, 1-13.

[28] Winter, M., Fitzgerald, M.A., Heck, R.K.Z., Haynes, G.W. and Danes, S.M. (1998) Revisiting the Study of Family Businesses: Methodological Challenges, Dilemmas, and Alternative Approaches. Family Business Review, 11, $239-252$. http://dx.doi.org/10.1111/j.1741-6248.1998.00239.x

[29] Lawrence, P.R. and Lorsch, J.W. (1967) Organization and Environment: Managing Differentiation and Integration. Irwin, Homewood

[30] Kellermanns, F.W. and Eddleston, K.A. (2004) Feuding Families: When Conflict Does a Family Firm Good. Entrepreneurship Theory and Practice, 28, 209-228. http://dx.doi.org/10.1111/j.1540-6520.2004.00040.x

[31] Harvey, M. and Evans, R.E. (1994) Family Business and Multiple Levels of Conflict. Family Business Review, 7, 
331-348. http://dx.doi.org/10.1111/j.1741-6248.1994.00331.x

[32] Berrone, P., Cruz, C. and Gomez-Mejia, L.R. (2012) Socioemotional Wealth in Family Firms: Theoretical Dimensions, Assessment Approaches, and Agenda for Future Research. Family Business Review, 25, 258-279. http://dx.doi.org/10.1177/0894486511435355

[33] Association of Chinese Management Science (ACMS) (1993) The Road to Success of Family-Type Enterprise. Taipei.

[34] Bhaumik, S.K., Driffield, N. and Pal, S. (2010) Does Ownership Structure of Emerging Market Firms Affect Their Outward FDI? The Case of Indian Automotive and Pharmaceutical Sectors. Journal of International Business Studies, 41, 437-450. http://dx.doi.org/10.1057/jibs.2009.52

[35] Carney, M. (2005) Globalization and the Renewal of Asian Business Networks. Asia Pacific Journal of Management, 22, 337-354. http://dx.doi.org/10.1007/s10490-005-4114-z

[36] Chung,H.M. (2013) The Role of Family Management and Ownership on Semi-Globalization Pattern of Globalization: The Case of Family Business Groups. International Business Review, 23, 260-271. http://dx.doi.org/10.1016/j.ibusrev.2013.04.005

[37] Erdener, C. and Shapiro, D.M. (2005) The Internationalization of Chinese Family Enterprises and Dunning's Eclectic MNE Paradigm. Management and Organization Review, 1, 411-436. http://dx.doi.org/10.1111/j.1740-8784.2005.00021.x

[38] Tsang, E.W.K. (2002) Learning from Overseas Venturing Experience: The Case of Chinese Family Businesses. Journal of Business Venturing, 17, 21-40. http://dx.doi.org/10.1016/S0883-9026(00)00052-5

[39] Peters, T. and Waterman Jr., R. (1982) In Search of Excellence. Harper Collins, New York.

[40] Chung, C.N. and Luo, X.W. (2008) Institutional Logics or Agency Costs: The Influence of Corporate Governance Models on Business Group Restructuring in Emerging Economies. Organization Science, 19, 766-784. http://dx.doi.org/10.1287/orsc.1070.0342

[41] Hamermesh, D.S. and Pfann, G.A. (1994) Adjustment Costs in Factor Demand. Journal of Economic Literature, 34, 1264-1292.

[42] Rogoff, E.G. and Heck, R.K.Z. (2003) Evolving Research in Entrepreneurship and Family Business: Recognizing Family as the Oxygen that Feeds the Fire of Entrepreneurship. Journal of Business Venturing, 18, 559-566. http://dx.doi.org/10.1016/S0883-9026(03)00009-0

[43] Danes, S.M., Lee, J., Stafford, K. and Heck, R.K.Z. (2008) The Effects of Ethnicity, Families and Culture on Entrepreneurial Experience: An Extension of Sustainable Family Business Theory. Journal of Developmental Entrepreneurship, 13, 229-268. http://dx.doi.org/10.1142/S1084946708001010

[44] Heck, R.K.Z., Danes, S.M., Fitzgerald, M.A., Haynes, G.W., Jasper, C.R., Schrank, H.L., Stafford, K. and Winter, M. (2006) The Family’s Dynamic Role within Family Business Entrepreneurship. In: Poutziouris, P.Z., Smyrnios, K.X. and Klein, S.B., Eds., Handbook of Research on Family Business, Edward Elgar Publishers, Cheltenham, 80-105. http://dx.doi.org/10.4337/9781847204394.00014

[45] Stafford, K., Duncan, K.A., Danes, S.M. and Winter, M. (1999) A Research Model of Sustainable Family Businesses. Family Business Review, 12, 197-208. http://dx.doi.org/10.1111/j.1741-6248.1999.00197.x

[46] Lin, W.T. (2014) Founder-Key Leaders, Group-Level Decision Teams, and the International Expansion of Business Groups Evidence from Taiwan. International Marketing Review, 31, 129-154. http://dx.doi.org/10.1108/IMR-07-2012-0120

[47] Collins, L., Seaman, C., Graham, S. and Stepek, M. (2013) The Future of Family Businesses Education in UK Business Schools. Education+ Training, 55, 445-460.

[48] Sandhu, N., Hussain, J. and Matlay, H. (2012) Entrepreneurship Education and Training Needs of Family Businesses Operating in the Agricultural Sector of India. Education+ Training, 54, 727-743.

[49] Kansikas, J. and Laakkonen, A. (2009) Students’ Perceptions of Family Entrepreneurship—A Study on Family Business Academic Education. Management International, 14, 55-65.

[50] Peters, M. and Buhalis, D. (2004) Family Hotel Businesses: Strategic Planning and the Need for Education and Training. Education+ Training, 46, 406-415.

[51] Ibrahim, A.B., Soufani, K. and Lam, J. (2003) Family Business Training: A Canadian Perspective. Education+ Training, 45, 474-482.

[52] Swierczek, F.W., Shrestha, P.K. and Bechter, C. (2005) Information Technology, Productivity, and Profitability in Asia-Pacific Banks. Journal of Global Information Technology Management, 8, 6-26. http://dx.doi.org/10.1080/1097198X.2005.10856388

[53] Niehm, L.S., Tyner, K., Shelley, M.C. and Fitzgerald, M.A. (2010) Technology Adoption in Small Family-Owned Businesses: Accessibility, Perceived Advantage, and Information Technology Literacy. Journal of Family and Eco- 
nomic Issues, 31, 498-515. http://dx.doi.org/10.1007/s10834-010-9197-0

[54] Farhanghi, A.A., Abbaspour, A. and Ghassemi, R.A. (2013) The Effect of Information Technology on Organizational Structure and Firm Performance: An Analysis of Consultant Engineers Firms (CEF) in Iran. Procedia-Social and Behavioral Sciences, 81, 644-649. http://dx.doi.org/10.1016/j.sbspro.2013.06.490

[55] Chevers, D.A. and Chevers, J.E. (2014) The Impact of Information Technology Material Weakness on Corporate Governance Changes in Family-Owned Businesses. International Journal of Business and Social Science, 5, 87-96.

[56] Myrie, J. and Daly, K. (2009) The Use of Boundaries by Self Employed Home Based Workers to Manage Work and Family: A Qualitative Study in Canada. Journal of Family and Economic Issues, 30, 386-398. http://dx.doi.org/10.1007/s10834-009-9166-7

[57] Haislip, J.Z., Masli, A., Richardson, V.J. and Sanchez, J.M. (2012) Information Technology Material Weaknesses and Corporate Governance Changes.Unpublished Manuscript.

[58] Selekler-Goksen, N. and YildirimÖktem, Ö. (2009) Countervailing Institutional Forces: Corporate Governance in Turkish Family Business Groups.Journal of Management \& Governance, 13, 193-213. http://dx.doi.org/10.1007/s10997-009-9083-z

[59] Yasser, Q.R. (2011) Challenges in Corporate Governance-A Family Controlled Business Prospective.International Journal of Innovation, Management and Technology, 2, 73.

[60] Sicoli, G. (2013) Role of Corporate Governance Business in the Family Business. The Global Conference on Business and Finance Proceedings, 8, 8-16.

[61] Bai, C.E., Liu, Q., Lu, J., Song, F.M. and Zhang, J.X. (2004) Corporate Governance and Market Valuation in China. Journal of Comparative Economics, 32, 599-616. http://dx.doi.org/10.1016/j.jce.2004.07.002 
Scientific Research Publishing (SCIRP) is one of the largest Open Access journal publishers. It is currently publishing more than 200 open access, online, peer-reviewed journals covering a wide range of academic disciplines. SCIRP serves the worldwide academic communities and contributes to the progress and application of science with its publication.

Other selected journals from SCIRP are listed as below. Submit your manuscript to us via either submit@scirp.org or Online Submission Portal.
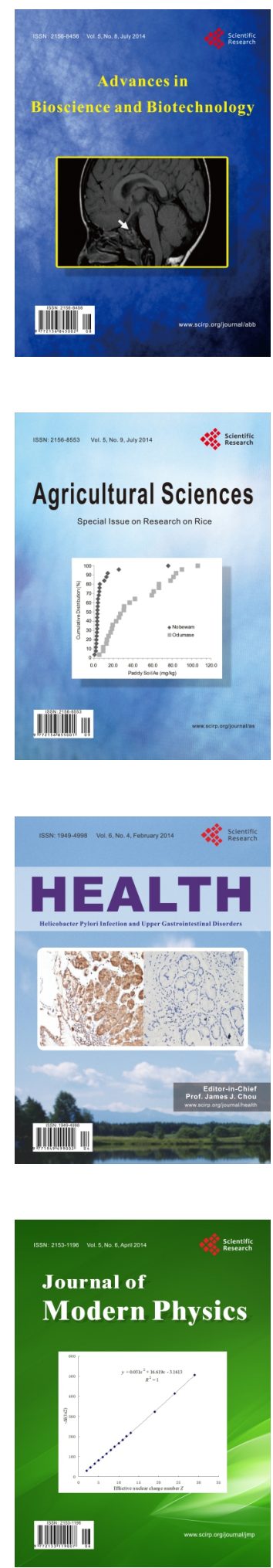
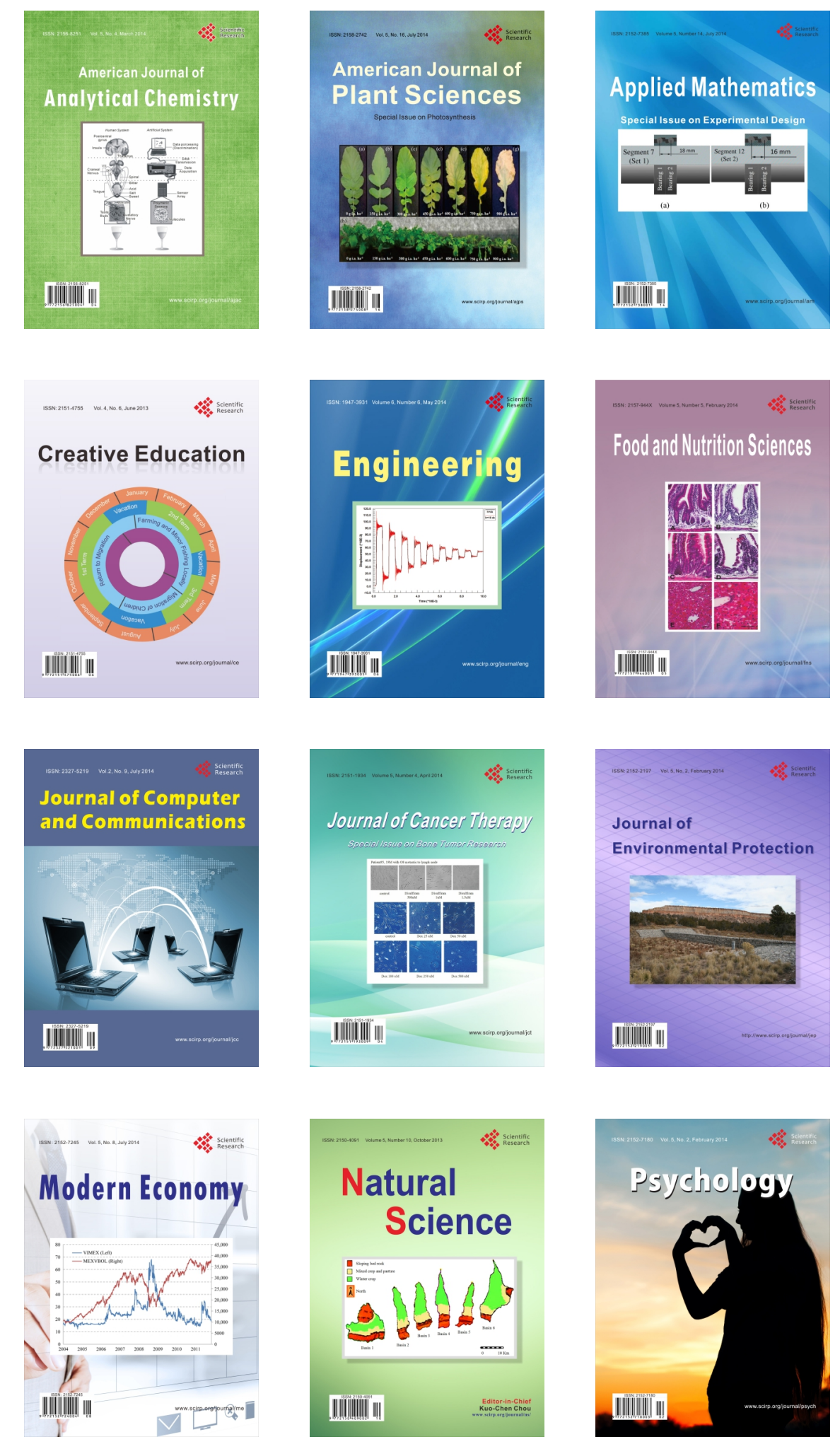